\title{
Birleştirme tekniğine dayalı öğretimin çevre sorunlarına yönelik tutum akademik başarı ve kalıcılığa etkisi
}

\author{
Gökhan Uyanık \\ Kastamonu Üniversitesi, Eğitim Fakültesi, Kastamonu, Türkiye, guyanik@kastamonu.edu.tr
}

ÖZ Bu araştırmanın amacı, birleştirme tekniğine dayalı çevre eğitiminin lisans öğrencilerinin akademik başarıları, çevre sorunlarına yönelik tutumları ve öğrenmenin kalıcılığına etkisini belirlemektir. Araştırmada öntest-sontest kontrol gruplu yarı deneysel desen kullanılmıştır. Çalışma grubu, Kastamonu Üniversitesi Eğitim Fakültesi Sınıf Öğretmenliği lisans programı dördüncü sınıfta iki farklı şubede öğrenim gören 63 öğrenciden oluşmaktadır. Seçkisiz atama yoluyla belirlenen deney grubunda 30 öğrenci, kontrol grubunda ise 33 öğrenci bulunmaktadır. Veriler, Güven (2013) tarafından geliştirilen çevre sorunları başarı testi ve Şama (2003) tarafından geliştirilen çevre sorunlarına yönelik tutum ölçeği ile toplanmıştır. Veriler SPSS 21.0 istatistik paket programı üzerinde bağımsız t-testi ile analiz edilmiştir. Araştırmanın sonunda, deney ve kontrol grubunun hem başarı testi hem de tutum ölçeği son-test puanları arasında deney grubu lehine istatistiksel olarak anlamlı bir fark olduğu belirlenmiştir. Bununla birlikte, deney ve kontrol grubunun kalıcılık testi puanları arasında da deney grubu lehine istatistiksel olarak anlamlı bir fark olduğu tespit edilmiştir.

Anahtar

Birleştirme tekniği, çevre, tutum, kalıcılık

\section{The effect of jigsaw technique on attitudes towards environmental problems academic achievement and retention}

ABSTRACT The purpose of this research is to determine the effect of the jigsaw technique on degree students' academic achievements, attitudes towards environmental problems and learning retention. Pretest-posttest quasi-experimental design was used in this study. The working group was comprised of 63 degree students in Kastamonu University Faculty of Education. The experimental group consists of 30 students and control group consists of 33 students. Data were collected through achievement test of environmental problems developed by Güven (2013) and attitude scale of environmental problems developed by Şama (2003). Independent t-test analysis were done for analysis of data. At the end of the research, results showed that a statistically significant difference between the experimental and control groups' achievement test and attitude scale scores in favor of experimental group. Moreover it was determined that a statistically significant difference between the experimental and control groups retention test scores in favor of experimental group. 


\section{EXTENDED SUMMARY}

Environmental education provides for people to increase awareness about events of environment and acquisition of necessary knowledge for the solution of environmental problems. Due to the young people most affected by environmental problems, the first target audience of environmental education are the younger generation. It is important that to have the motivation and desire to participate actively in the protection of environmental values, therefore the younger generation must be encountered in global awareness and sensitivity about the environmental problems. In this sense, environmental education courses has a great importance at universities. In the literature, it is emphasis that the importance of quality environmental education in studies with college students. Therefore it is necessary to effective teaching. Using appropriate teaching techniques and methods for teaching must be make effective. One of these effective teaching techniques and methods is the jigsaw technique in cooperative learning method. Cooperative learning that a teaching method of improvement students' academic achievement, self-esteem, self-efficacy, attitude and positive social skills. Want to teaching environmental education and ensuring the development of positive attitudes towards environment to increase the students' desire to learnings and motivations are important. To achieve this, firstly it is necessary to determine the appropriate methods and techniques to be used. In this context, it is expect that to determine the positive and negative sides of trying different methods the various topics of environmental education can contribute to the literature. The jigsaw technique, which is a technique of cooperative learning method. Students are formed in groups of 3-7 person in the jigsaw technique. Each cluster is given the same unit and is required to choose one of the topics of the cluster members. Each member of different groups after working on their own agenda and discuss issues come together on the same subject area when they return to their original groups. Issues they prepare together again group members are obliged to teach from each other. Students in this technique they assume the role of both teacher and student. Hence the purpose of this study is to determine the effect of jigsaw technique based environmental education on the academic achievements, attitudes towards environmental problems and retention of learnings. For this purpose, searched answers to the following sub-problems:

1) Is there a significant difference between the achievement test of environmental problems and attitude scale of environmental problems pre-test scores of experimental and control group?

2) Is there a significant difference between the achievement test of environmental problems and attitude scale of environmental problems post-test scores of experimental and control group?

3) Is there a significant difference between the retention test scores of experimental and control group? Pretest-posttest quasi-experimental design was used in this research. The working group was comprised of 63 degree students in Kastamonu University Faculty of Education. The experimental group consists of 30 students and control group consists of 33 students. Lessons in the experimental group were processed based on the jigsaw technique. It had been taught in the control group in accordance with the existing curriculum. Data were collected through achievement test of environmental problems developed by Güven (2013) and attitude scale of environmental problems developed by Şama (2003). For analysis the data independent t-test analysis were done on the SPSS 21.0 statistical software package. Data were tested on $\mathrm{p}<.05$ level of significance.

After the analysis, results showed that a statistically significant difference between the experimental and control group achievement test and attitude scale towards environmental problems post-test scores in favor of experimental group. However it was determined that a statistically significant difference between the experimental and control group retention test scores in favor of experimental group. Based on these results, jigsaw technique which was applied in experimental group it is said to be more effective to provide increase students' academic achievements and retentivity of learnings. At the same time it can be interpreted the effectiveness of jigsaw technique to develop positive attitudes towards environmental problems.

In this study, the jigsaw technique was used to teaching which was based on the constructivist learning approaches of cooperative learning techniques. It was shown that the environmental education based on jigsaw technique was statistically significant increased academic achievement of students at the end of the study. This results supports that the difference researches' results, using jigsaw technique, in literature. A positive impact on students' attitudes at different grade levels of cooperative learning techniques were demonstrated similarity some researches in literature. At the same time in this study, it was concluded that the jigsaw technique which was effective to development of positive attitudes, it was 
one of the teaching techniques of cooperative learning. Moreover, it was determined to be statistically difference between experimental and control group retention test scores' in favor of experimental group. According to this, it can be said that the teaching based on jigsaw technique, which was applied in the experimental group, to provide more retentive learning. Obtained this result has been similar to the results of researches in the literature. In this sense, it is recommended that to extend using cooperative learning techniques in environmental education courses of universities degree programs. In this regard, it is recommended that using to jigsaw technique teaching at different subjects of environmental education courses. The next researches, it can be examine the effectiveness of jigsaw technique in universities' different degree programs and different courses. 


\section{GİRIŞ}

Günümüzde giderek artan nüfus, teknolojide meydana gelen gelişmeler ve toplumların değiş̧en yaşam tarzı ile alışkanlıklarının yol açtı̆̆ çevre sorunları, doğal kaynaklarda azalma ve bozulmalara neden olmuş özellikle son yarım yüzyılda tüm yaşam sistemlerini tehdit altına almıştır (Deniş ve Genç, 2007). Çevre sorunlarının olumsuz etkilerinin ortadan kaldırılması için çevre eğitimine önemli görevler düşmektedir. Çevre eğitimi, çevre ile ilgili olaylara yönelik farkındalığın artmasını ve çevre sorunlarının çözümü için gerekli davranışların kazanılmasını sağlamaktadır (Milton, Cleveland ve Bennett-Gates, 1995).

Erol ve Gezer (2006) çevre sorunlarından en çok etkilenecek kesim olması nedeniyle çevre eğitiminin öncelikli hedef kitlesi olarak genç nesli göstermektedir. Bu nedenle, genç neslin küresel ölçekte karşılaşılan çevre sorunlarına dair farkındalık ve duyarlılık sahibi olması, çevresel değerleri korumaya aktif olarak katılmak için motivasyon ve istek sahibi olması önemlidir (Baş, 2011; UNESCO, 1977). Özellikle, üniversite öğrencilerinin eğitimleri sırasında edindikleri çevre ile ilgili bilgi, beceri, tutum ve değerleri profesyonel meslek hayatlarına başlamalarıyla birlikte kişisel ve sosyal yaşamlarında uygulamaları, üniversite öğrencilerinden beklenen bir sorumluluk olarak görülmektedir (Teksöz, Şahin ve Ertepınar, 2010). Bu nedenle, yükseköğretim programlarında yer alacak çevre eğitimi ile ilgili derslerle üniversite öğrencilerinin, çevre meselelerinin altında yatan nedenleri, gerçekleri anlayabilmesi, ekonomik, yasal ve politik mekanizmaların çevre sorunları ile ilişkilendirebilmesi sağlanmalıdır (Taştepe ve Aral, 2014).

Literatürde, üniversite öğrencileri ile yapılan çalışmalarda, çevre eğitiminin önemine vurgu yapılmaktadır. Keleş (2007), sürdürülebilir yaşama yönelik üniversite öğrencilerinin farkındalık, tutum ve davranışlarının değiştirilmesinde çevre eğitimi aracı olarak ekolojik ayak izi uygulamasının etkili olduğu sonucuna ulaşmıştır. Yoldaş (2009), Çevre Bilimi Dersi Çevre Sorunları Ünitesi'nde eleştirel düşünme becerilerini temel alan öğretim uygulamalarının üniversite öğrencilerinin eleştirel düşünme becerilerinde, erişilerinde ve çevre tutumlarında olumlu etkileri olduğunu belirlemiş̧tir. Keleş, Uzun ve Varnacı Uzun (2010), doğa eğitimi programının üniversite öğrencilerinin çevre bilincine, tutumlarına ve davranışlarına önemli ölçüde etki ettiğini ve kalıcılığını sağladığını tespit etmiştir. Çimen (2013), dönüşümsel öğrenme modeline dayalı çevre eğitiminin üniversite öğrencilerinin çevre sorunlarına yönelik bilgi, tutum, çevreye yönelik inanç ve çevreye duyarlı davranışlarında olumlu değişiklikler olduğunu belirtmiştir. Öztürk (2013), uluslararası bir çevre eğitimi programı olan Yeşil Kutu Projesi'nin üniversite öğrencilerinin çevreye yönelik davranışlarını ve bilgi düzeylerini geliştirdiğini vurgulamıştır. Çevre eğitiminin temeli doğayı ve doğal kaynakları korumaya yöneliktir. Çevre eğitimi bilgi vermenin yanında insan davranışını da etkilemelidir. Olumlu ve kalıcı davranış değişiklikleri kazandırmak ve sorunların çözümünde bireylerin aktif katılımını sağlamak çevre eğitiminin temel hedefidir (Şimşekli, 2004). Çevre eğitiminde kullanılan geleneksel yaklaşımların çevre sorunlarının giderilmesinde başarılı olmadığı görülmektedir (Çimen ve Yılmaz, 2014). Bu nedenle, okullarda verilen çevre eğitiminde öğrencilerin aktif olarak öğrenme sürecinde yer alacağı öğrenme yöntemlerinin kullanılması gerekmektedir. Bu anlamda, öğrenmenin daha etkili ve daha kalıcı olabilmesi için öğrencinin bilgiyi alacak şekilde aktif hale gelmesini sağlamak önemlidir. Öğrencinin aktif katılımının olmadığı öğrenme süreçlerinde öğretilmeye çalışılan bilgiler, öğrenci açısından yüzeyde kalacaktır. Bu sebeple öğrenme süreçlerinde öğrencilerin sürece aktif katılımı önem taşımaktadır. Öğrencilerin öğrenme sürecine aktif katılımıyla öğrenmeyi daha etkili kılmayı amaçlayan yöntemler aktif öğrenme yöntemleri olarak adlandırılmaktadır. Aktif öğrenme yöntemleri, bilginin öğrencinin kendi yaşantısıyla, kendi aktif katılımlarıyla edinilebileceği temeline dayanır (Açıkgöz, 2003).

Yapılandırmacı yaklaşım temeline dayanan aktif öğrenme yöntemlerinden biri de işbirlikli öğrenme yöntemidir. İşbirlikli öğrenme; aktif rolü öğrencinin üstlendiği öğrenci merkezli bir öğrenim yöntemidir (Cooper ve Mueck, 1990). Bu yönteme göre öğrenciler ortak bir amaç için ortaklaşa çalışırlar ve bunu küçük gruplar kurarak gerçekleştirirler.

İşbirlikli öğrenmede, öğrencinin kendisinin ve arkadaşlarının en üst seviyede çaba göstermeleri ve öğrenme gayreti içinde olmaları gerekir. Johnson, Johnson ve Smith (1998)'e göre iş birliğine dayalı öğrenme, ortak öğrenme amaçlarını maksimum düzeyde gerçekleştirmek üzere öğrencilerin küçük gruplar hâlinde iş birliği içerisinde birlikte çalışması esasına dayalı interaktif bir öğrenme-öğretme metodu olarak tanımlanmaktadır. İşbirliğine dayalı öğrenme yöntemi, her sınıf düzeyinde, her ders ve 
konu alanının öğretiminde başarı ile uygulanabilecek bir öğrenme metodudur (Choe ve Drennan, 2001; Stainer, 1999).

Araştırmacılar öğrenciler küçük gruplar halinde birlikte çalıştıklarında öğretilenleri daha iyi öğrendiklerini ve öğretilenlerin daha fazlasını öğrencilerin belleğinde tuttuklarını, öğrencilerin sınıf arkadaşlarıyla çalıştıkları çevre ile daha uyumlu olduklarını diğer geleneksel yöntemlerle karşılaştırarak tespit etmişlerdir (Bilgin ve Geban; 2004). İşbirlikli öğrenme teknikleri, sosyal kabulü geliştirmekte ve arkadaşlığı teşvik etmekte ayrıca, akademik başarıyı ve öz saygıyı arttırmaktadır (Madden ve Slavin, 1983; akt: Köseoğlu, 2010).

Öğretim ortamında özel amaçlara ulaşmayı sağlayan pek çok işbirlikli öğrenme tekniği bulunmaktadır. Bu tekniklerden biri de Birleştirme Tekniği' dir. Birleştirme tekniğinde öğrenciler arasında 3-7 kişilik gruplar oluşturulmaktadır. Her kümeye aynı ünite verilmekte ve küme üyelerinden konulardan birini seçmesi istenmektedir. Her üye kendi konusuna çalıştıktan sonra farklı kümelerde aynı konuyu alan üyeler "uzmanlık kümelerinde" bir araya gelmekte ve konu üzerinde tartışıp kendi asıl gruplarına geri dönmektedirler. Yeniden bir araya gelen grup üyeleri hazırladıkları konuları birbirlerine öğretmekle yükümlüdürler. Onlara bunun için belli bir süre verilmekte ve bu sürenin sonunda bireysel olarak sinava girecekleri söylenmektedir. Bu süreçte öğrenciler hem öğretmen hem de öğrenci rolünü üstlenmektedirler. $\mathrm{Bu}$ şekilde, birkaç öğrencinin baskın olduğu bir ortam yerine herkesin katkısının değerli olduğu bir ortam oluşturulmaktadır (Köseoğlu, 2010).

Slavin (1991), işbirlikli öğrenmenin öğrencilerin akademik başarı, öz-sayg1, öz-yeterlik, tutum ve pozitif sosyal beceriler konusunda gelişimlerini sağlayan bir öğretim yöntemi olduğunu vurgulamıştır. Çevre eğitimi ile öğretilmek istenenlerin ve çevreye yönelik olumlu tutum geliştirilmesini sağlamada öğrencilerin öğrenmeye karşı isteklerinin ve motivasyon düzeylerinin artırılması önem taşımaktadır. Bunu gerçekleştirebilmek için de öncelikle kullanılacak uygun öğretim yöntem ve tekniklerinin belirlenmesi gerekmektedir. Bu bağlamda, çevre eğitimi dersinin çeşitli konularında farklı yöntemler denenerek olumlu olumsuz yanlarının belirlenmesinin literatüre katkı sağlayacağı düşünülmektedir. Birleştirme tekniğinin, işbirlikli öğrenmenin diğer tekniklerine göre üzerinde az çalışılmış tekniklerden biri olması da bu araştırmayı önemli ve gerekli kılan bir nedendir. Buradan hareketle bu çalışmanın amacı, birleştirme tekniği temelli öğretime dayalı çevre eğitiminin akademik başarı, çevre sorunlarına yönelik tutum ve öğrenmenin kalıcılığına etkisini belirlemektir. Bu amaçla aşağıdaki alt problemlere cevap aranmiştır:

Birleştirme tekniğine dayalı çevre eğitiminin uygulandığı deney grubu ile mevcut öğretim programının uygulandığ kontrol grubunu;

Çevre sorunları başarı testi ve çevre sorunlarına yönelik tutum ölçeği ön-test puanları arasında anlamlı bir fark var midir?

Çevre sorunları başarı testi ve çevre sorunlarına yönelik tutum ölçeği son-test puanları arasında anlamlı bir fark var midir?

Kalıcılık testi puanları arasında anlamlı bir fark var midır?

\section{YÖNTEM}

\section{Araştırmanın Modeli}

$\mathrm{Bu}$ araştırmada öntest-sontest kontrol gruplu yarı deneysel desen kullanılmıştır. Öntest-sontest kontrol gruplu desenin iki temel avantajı vardır. Birincisi, aynı denekler üzerinde ölçümler yapıldığından farklı deneysel işlem koşulları altında elde edilen ölçümler pek çok deneyde yüksek düzeyde ilişkili olacaktır. $\mathrm{Bu}$ da hata terimini düşürecek ve buna bağlı olarak istatistiksel güç artacaktır. İkinci avantaj ise, daha az denek gerektirir ve her bir işlemde aynı denekleri test etmeye bağlı olarak zaman ve sarf edilen çabada daha bir ekonomiklik sağlar (Büyüköztürk, Çakmak, Akgün, Karadeniz ve Demirel, 2009: 202). Araştırmanın deneysel desenine ilişkin simgesel görünüm Tablo 1'de yer almaktadır.

Tablo 1. Araştırmanın Deneysel Desenine İlişkin Simgesel Görünüm

\begin{tabular}{ccccc}
\hline Grup & Ön-test & İşlem & Son-test & Kalıc1lı Testi \\
\hline Deney & T1 $-\ddot{O ̈ 1}$ & $\mathrm{X}$ & $\mathrm{T} 1-$ Ö1 & T1 \\
Kontrol & $\mathrm{T} 1-$ Ö1 & - & $\mathrm{T} 1-$ Ö1 & $\mathrm{T} 1$
\end{tabular}

$\mathrm{T} 1=$ çevre sorunları başarı testi; $\overline{\mathrm{O}} 1=$ =çevre sorunlarına yönelik tutum ölçeği; $\mathrm{X}=$ birleştirme tekniğine dayalı çevre eğitimi 
Tablo 1'e göre, deneysel işlem öncesinde deney ve kontrol grubuna başarı testi ve tutum ölçeği ön-test olarak uygulanmıştır. Deneysel uygulama süreci 5 haftalık bir süreyi kapsamaktadır. Deneysel uygulama süreci boyunca deney grubunda dersler birleştirme tekniğine dayalı olarak işlenmiştir. Kontrol grubunda ise dersler mevcut öğretim programı doğrultusunda yürütülmüştür. 5 haftalık deneysel uygulama sürecinin sonunda başarı testi ve tutum ölçeği her iki gruba da son-test olarak uygulanmıştır. 5 haftalık deneysel uygulama sürecinin bitiminden 6 hafta sonra, her iki gruba kalıc1lık testi uygulanmıştır.

\section{Çalışma Grubu}

Araştırmanın çalışma grubunu, 2014-2015 eğitim-öğretim yılı güz döneminde Kastamonu Üniversitesi Eğitim Fakültesi Sınıf Öğretmenliği lisans programı dördüncü sınıfta öğrenim gören iki farklı sınıftaki 63 öğretmen adayı oluşturmaktadır. Sınıflardan biri deney, diğeri kontrol grubu olarak hali hazırda bulunan gruplardan rasgele seçilmiş̧tir. Deney grubunda 30 öğrenci bulunurken, kontrol grubunda 33 ögrenci yer almaktadır.

\section{Veri Toplama Araçları}

Araştırmada veri toplama araçları olarak, Güven (2013) tarafından geliştirilen "Çevre Sorunları Başarı Testi" (ÇSBT) ve Şama (2003) tarafından geliştirilen "Çevre Sorunlarına Yönelik Tutum Ölçeği" (ÇSYTÖ) kullanılmıştır. Çevre sorunları başarı testi " 55 " sorudan oluşmaktadır. Testin orijinal haline ilişkin KR-20 değeri .87 olarak hesaplanmıştır. Bu araştırmada hesaplanan KR-20 değeri ise .84 olarak belirlenmiştir. Testte bulunan maddelerin ortalama güçlüğü .49, standart sapması ise 9.80 olarak belirlenmiştir. Geliştirilen testin kapsam geçerliğini sağlamak amacıyla uzman görüşleri alınmıştır. Testte doğru cevaplandırılan her sorunun değeri "1" puan olarak değerlendirilmiştir. Bu durumda testten alınabilecek en yüksek puan "55" olarak belirlenmiştir. Çevre sorunlarına yönelik tutum ölçeği " 21 " maddeden oluşmaktadır. Ölçeğin kapsam geçerliği için uzman görüşleri alınmıştır. Ölçek 5'li likert tipinde olup, ölçekte yer alan seçenekler "kesinlikle katılmıyorum", "katılmıyorum", "kararsızım", "katılıyorum" ve "kesinlikle katılıyorum" şeklinde verilmiştir. Ölçekte yer alan maddelerden 10'u olumsuz 11'i ise olumludur. Orijinal haline ilişkin Cronbach Alpha $(\alpha)$ güvenirlik katsayısı değeri .77 olan ölçek tek boyuttan oluşmaktadır. Ölçeğin bu araştırma için belirlenen güvenirlik katsayısı değeri .76 olarak hesaplanmıştır. 21 maddelik tutum ölçeğinde en olumlu cevap "5" puan ve en olumsuz cevap "1" puan olarak değerlendirilmiştir. Bu şekilde ölçekten alınabilecek en yüksek puan "105" ve en düşük puan " 21 " olarak belirlenmiştir.

\section{Uygulama Süreci}

Araştırma boyunca birleştirme tekniğine dayalı öğretimin uygulama basamakları şu şekilde gerçekleştirilmiştir:

Uygulama öncesinde hem deney hem de kontrol grubu öğrencilerine Çevre Sorunları Başarı Testi (ÇSBT) ve Çevre Sorunlarına Yönelik Tutum Ölçeği (ÇSYT) ön-test olarak uygulanmıştır. Deney grubunda bulunan 30 öğrenciden 5 kişilik 6 karma grup oluşturulmuştur ve bu gruplara asıl gruplar olarak isimler verilmiştir.

Çevre Eğitimi dersi kapsamında Hava Kirliliği, Su Kirliliği, Toprak Kirliliği, Geri Dönüşüm ve Küresel Isınma konuları 5 alt konu olarak belirlenmiştir. Grup üyelerinin yüz yüze etkileşime olanak sağlayacak şekilde sınıfta "U" düzeninde oturmaları sağlanmıştır. Konuları, gruplarda yer alan 5 öğrencinin kendi aralarında paylaşmaları istenmiş ve her öğrenci için konusuna göre hazırlanan ve gruplara göre renkleri farklı olan yaka kartları verilmiştir.

Gruplar konu dağılım çizelgesi oluşturduktan sonra öğrencilerden toplanmıştır. Grup bütünlügünün sağlanması amacıyla her grubun kendisine bir isim belirlemesi istenmiştir. Öğrencilerden bir sonraki derse gelmeden önce seçtikleri konuya iyice hazırlanmaları ve yararlandıkları kaynakları sınıf ortamına getirmeleri istenmiştir. Ayrıca, diğer arkadaşlarının konularını da kısaca incelemeleri ve arkadaşlarına konularıyla ilgili sorabilecekleri soruları yazmaları söylenmiştir.

Bir sonraki ders başladığında, aynı konuyu alan öğrencilerin bir araya gelmeleri istenmiş ve aynı konuyu alanlardan oluşan kümelere uzmanlık kümeleri denmiştir. Dolayısıyla, beş alt konuyla ilgili olarak beş adet uzmanlık kümesi oluşturulmuştur. Öğrenciler uzmanlık kümelerinde aynı konuyu alan arkadaşlarıyla, konuyu kapsamlı bir şekilde tartışmışlardır. Konuyla ilgili olarak birbirlerine sorular 
yöneltmişlerdir. Konuyu iyice kavramaya çalışmışlar ve kendileri için gerekli gördükleri notları almışlardır.

Öğrenciler, uzmanlık kümelerinde 5 haftalık süreçte toplam 5 ders saati çalıştıktan sonra, diğer 5 ders saatinde kendi kümelerine dönmüşler ve sorumlu oldukları konuları, sırayla küme arkadaşlarına anlatmışlardır. Bu arada, küme üyeleri konusunu anlatan arkadaşlarına sorular yöneltmişler ve konuyu iyice kavramaya çalışmışlardır. Öğrenciler, küme içinde kendileri için gerekli gördükleri noktalar ile ilgili olarak notlar tutmuşlardır. Kontrol grubunda ise dersler öğretmen merkezli yöntemle 5 hafta süresince toplam 10 saat işlenmiştir. 5 haftalık uygulama sürecinin sonunda deney ve kontrol grubu öğrencilerine son-test olarak çevre sorunları başarı testi, çevreye duyarlı davranış ölçeği ve çevre sorunlarına yönelik tutum ölçeği uygulanmıştır. Son-test olarak uygulanan ölçekler, 5 haftalık deneysel uygulama sürecinin bitiminden 6 hafta sonra kalıcılık testi olarak tekrar uygulanmıştır.

\section{Verilerin Analizi}

Araştırma sonucunda elde edilen veriler SPSS 21.0 istatistik paket program kullanılarak çözümlenmiştir. Yapılan istatistiki analizler sonucunda verilerin normal dağılım gösterdiği belirlenmiş̦tir. Bu nedenle deney ve kontrol gruplarının puanlarını karşılaştırmak amacıyla bağımsız t-testi kullanılmıştır. Veriler $\mathrm{p}<.05$ anlamlılık düzeyinde test edilmiştir.

\section{BULGULAR}

\section{Birinci Alt Probleme İlişkin Bulgular}

Deneysel uygulama öncesinde deney ve kontrol grubunun çevre sorunlarına ilişkin akademik başarı düzeylerini belirlemek amacıyla "Çevre Sorunları Başarı Testi" ön-test olarak kullanılmıştır. Yapılan ön-test sonucunda elde edilen puanları karşılaştırmak için bağımsız t-testi uygulanmıştır. Bağımsız ttesti sonuçlarına ilişkin bulgular Tablo 2'de yer almaktadır.

Tablo 2. Akademik Başarı Testi Ön-test Puanlarına İlişkin Bağımsız t-Testi Sonuçları

\begin{tabular}{lcccccc}
\hline \multicolumn{1}{c}{ Grup } & $\mathrm{N}$ & $\bar{X}$ & $\mathrm{SS}$. & $\mathrm{Sd}$ & $\mathrm{t}$ & $\mathrm{p}$ \\
\hline Deney & 30 & 23.66 & 4.91 & 61 & 1.280 & .205 \\
Kontrol & 33 & 22.09 & 4.85 & & & \\
\hline
\end{tabular}

Tablo 2'ye göre, deneysel uygulama öncesinde deney ve kontrol grubunun başarı testi ön-test puanları arasındaki farkın istatistiksel olarak anlamlı olmadığı belirlenmiştir $\left(t_{(61)}=1.280 ; p>.05\right)$. Bu bulguya bakarak, uygulama öncesinde deney ve kontrol grubunun çevre sorunları bilgisi akademik başarı düzeylerinin birbirine denk olduğu söylenebilir.

Deneysel uygulama öncesinde deney ve kontrol grubunun çevre sorunlarına yönelik tutumlarını belirlemek amacıyla "Çevre Sorunlarına Yönelik Tutum Ölçeği”" kullanılmıştır. Yapılan ön-test sonucunda elde edilen puanları karşılaş̧ırmak için bağımsız t-testi uygulanmıştır. Bağımsız t-testi sonuçlarına ilişkin bulgular Tablo 3 'de yer almaktadır.

Tablo 3. Tutum Ölçeği Ön-test Puanlarına İlişkin Bağımsız t-Testi Sonuçları

\begin{tabular}{ccccccc}
\hline Grup & $\mathrm{N}$ & $\bar{X}$ & $\mathrm{SS}$. & $\mathrm{Sd}$ & $\mathrm{t}$ & $\mathrm{p}$ \\
\hline Deney & 30 & 52.23 & 8.84 & 61 & 1.283 & .204 \\
Kontrol & 33 & 49.61 & 7.39 & & & \\
\hline
\end{tabular}

Tablo 3'de, deneysel uygulama öncesinde deney ve kontrol grubunun tutum ölçeği ön-test puanları arasında istatistiksel olarak anlamlı bir farkın olmadığı görülmektedir $\left(t_{(61)}=1.283 ; p>.05\right)$. Bu bulguya bakarak, uygulama öncesinde deney ve kontrol grubunun çevre sorunlarına yönelik tutumlarının birbirine benzer olduğu söylenebilir.

\section{İkinci Alt Probleme İlişkin Bulgular}

Deneysel uygulamanın sonunda deney ve kontrol grubunun akademik başarı düzeylerini belirlemek amacıyla akademik başarı testi son-test olarak kullanılmıştır. Yapılan son-test sonucunda elde edilen puanları karşılaştırmak için bağımsız t-testi uygulanmıştır. Bağımsız t-testi sonuçlarına ilişkin bulgular Tablo 4'de yer almaktadır. 
Tablo 4. Akademik Başarı Testi Son-test Puanlarına İlişkin Bağımsız t-Testi Sonuçları

\begin{tabular}{lcccccc}
\hline \multicolumn{1}{c}{ Grup } & $\mathrm{N}$ & $\bar{X}$ & $\mathrm{SS}$. & $\mathrm{Sd}$ & $\mathrm{t}$ & $\mathrm{p}$ \\
\hline Deney & 30 & 44.63 & 4.47 & 61 & 2.713 & $.009^{*}$ \\
Kontrol & 33 & 40.81 & 6.41 & & & \\
\hline
\end{tabular}

Tablo 4'e göre, deneysel uygulama sürecinin sonunda deney ve kontrol grubunun akademik başarı testi son-test puanları arasında deney grubu lehine istatistiksel olarak anlamlı bir fark olduğu belirlenmiştir $\left(t_{(61)}=2.713 ; p<.05\right)$. Bu bulgu, kontrol grubunda uygulanan mevcut öğretim programına göre, deney grubunda uygulanan birleştirme tekniği temelli çevre eğitiminin akademik başarıyı artırmada daha etkili olduğu şeklinde yorumlanabilir.

Deneysel uygulamanın sonunda deney ve kontrol grubunun çevre sorunlarına yönelik tutumlarını belirlemek amacıyla tutum ölçeği kullanılmıştır. Yapılan son-test sonucunda elde edilen puanları karşılaştırmak için bağımsız t-testi uygulanmıştır. Bağımsız t-testi sonuçlarına ilişkin bulgular Tablo 5'de yer almaktadir.

Tablo 5. Tutum Ölçeği Son-test Puanlarına İlişkin Bağımsız t-Testi Sonuçları

\begin{tabular}{lcccccc}
\hline \multicolumn{1}{c}{ Grup } & $\mathrm{N}$ & $\bar{X}$ & $\mathrm{SS}$. & $\mathrm{Sd}$ & $\mathrm{t}$ & $\mathrm{p}$ \\
\hline Deney & 30 & 80.36 & 6.21 & 61 & 2.379 & $.021^{*}$ \\
Kontrol & 33 & 76.51 & 6.61 & & & \\
\hline
\end{tabular}

Tablo 5'e bakıldığında deneysel uygulama sürecinin sonunda, deney ve kontrol grubunun tutum ölçeği son-test puanları arasındaki farkın deney grubu lehine istatistiksel olarak anlamlı olduğu görülmektedir $\left(t_{(61)}=2.379 ; p<.05\right)$. Bu bulguya göre, deney grubunda uygulanan birleştirme tekniği temelli çevre eğitiminin, kontrol grubunda uygulanan mevcut öğretim programına göre çevre sorunlarına yönelik olumlu tutum geliştirilmesinde daha etkili olduğu söylenebilir.

\section{Üçüncü Alt Probleme İliş̧kin Bulgular}

Deneysel uygulamanın bitiminden altı hafta sonra çevre sorunları başarı testi, kalıcıllk testi olarak tekrar kullanılmıştır. Yapılan kalıcılık testi sonucunda elde edilen puanları karşılaştırmak için bağımsız t-testi uygulanmıştır. Bağımsız t-testi sonuçlarına ilişkin bulgular Tablo 6'da yer almaktadır.

Tablo 6. Kalıcılık Testi Puanlarına İlişkin Bağımsız t-Testi Sonuçları

\begin{tabular}{lcccccc}
\hline \multicolumn{1}{c}{ Grup } & $\mathrm{N}$ & $\bar{X}$ & $\mathrm{SS}$. & $\mathrm{Sd}$ & $\mathrm{t}$ & $\mathrm{p}$ \\
\hline Deney & 30 & 43.73 & 1.91 & 61 & 17.345 & $.000^{*}$ \\
Kontrol & 33 & 29.51 & 4.11 & & & \\
\hline
\end{tabular}

Tablo 6' da yer alan sonuçlara göre, deney ve kontrol grubunun deneysel uygulamanın bitiminden 6 hafta sonra uygulanan kalıcılık testi puanları arasındaki farkın deney grubu lehine istatistiksel olarak anlamlı olduğu belirlenmiştir $\left(t_{(61)}=17.345 ; p<.05\right)$. Bu bulgudan yola çıkarak, mevcut öğretim programına göre birleştirme tekniğine dayalı öğretimin, öğrenmenin kalıcılığını artırdığı söylenebilir. Deney ve kontrol grubu öğrencilerinin çevre sorunları bilgisi akademik başarı düzeylerindeki değişime ilişkin çizgi grafiği Grafik 1'de görülmektedir. 


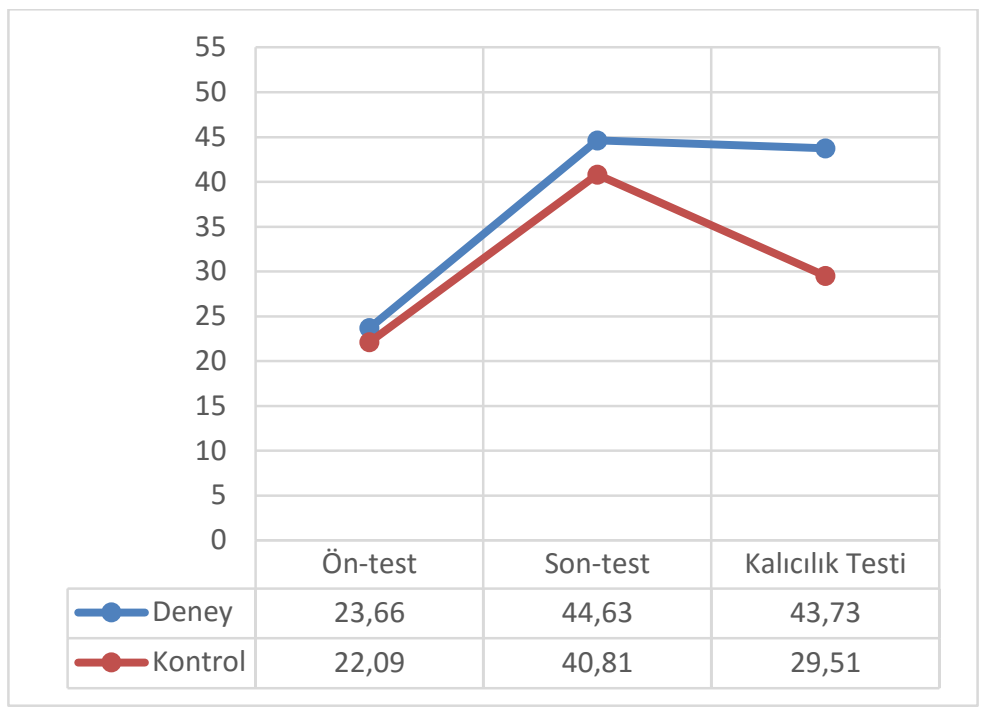

Grafik 1. Deney ve kontrol grubunun çevre sorunları bilgisi başarı düzeylerindeki değişim

Grafik 1 incelendiğinde, deneysel uygulama sürecinin başlangıcında, deney ve kontrol grubunun çevre sorunlarına ilişkin bilgi düzeylerinin benzer seviyede olduğu görülmektedir. Deneysel uygulama ile birlikte deney grubunun çevre sorunları bilgisi başarı düzeyleri kontrol grubuna göre daha fazla artış göstermiştir. Bundan daha önemlisi, uygulama sürecinin bitiminden altı hafta sonra yapılan kalıcılık testi sonuçlarına göre, deney grubunun başarı puanlarında anlamlı bir azalış olmadığı, kontrol grubunun puanlarının ise anlamlı ölçüde azaldığı belirlenmiştir. Bu sonuç, deney grubunda uygulanan birleştirme tekniğine dayalı çevre eğitiminin, öğrenmenin daha kalıcı gerçekleşmesini sağladığı şeklinde yorumlanabilir.

\section{TARTIŞMA ve SONUÇLAR}

$\mathrm{Bu}$ araştırmada yapılandırmacı öğrenme yaklaşımı temelinde, öğrenciyi merkeze alan işbirlikli öğrenme yönteminin öğretim tekniklerinden biri olan birleştirme tekniği kullanılmıştır. Deneysel uygulama öncesinde deney ve kontrol grubunun çevre sorunları başarı testi ön-test puanları arasında istatistiksel olarak anlamlı bir fark olmadığ tespit edilmiştir $\left(t_{(61)}=1.280 ; p>.05\right)$. Bu sonuca göre deneysel işlem öncesinde deney ve kontrol grubunun çevre sorunlarına ilişkin bilgi düzeylerinin benzer seviyede olduğu söylenebilir. Araştırmanın sonunda deney ve kontrol grubunun çevre sorunları başarı testi sontest puanları arasında deney grubu lehine istatistiksel olarak anlamlı bir fark olduğu belirlenmiştir $\left(t_{(61)}=\right.$ $2.713 ; p<.05)$. Buna göre, deney grubunda uygulanan birleştirme tekniğine dayalı çevre eğitiminin, akademik başarının artmasında etkili olduğu söylenebilir. Bu sonuç, literatürde yer alan farklı alanlarda ve farklı sınıf düzeylerinde birleştirme tekniği kullanılarak yapılan araştırmaların (Altıparmak ve Nakipoğlu, 2005; Arslan, Doğan-Bora ve Keskin-Samanc1, 2006; Artut ve Tarım, 2007; Doymuş, 2007; Ayna, Aktaş ve Koray, 2008; Choe ve Drennan, 2001; Doymuş ve Şimşek, 2007; Eilks, 2005; Ghaith \& Mirna; 2001; Hevedanl1, Behçet ve Akbayın, 2004; Karaçöp, Doymuş, Doğan ve Koç, 2009; Köseoğlu, 2010; Tarhan ve Acar-Şeşen, 2008) sonuçlarını destekler niteliktedir. Nitekim bu araştırmalarda da birleştirme tekniğine dayalı öğretimin, öğrencilerin başarıları üzerinde pozitif yönde anlamlı bir etkisi olduğu sonucuna ulaşılmıştır.

Deneysel uygulama sürecinin başlangıcında deney ve kontrol grubunun çevre sorunlarına yönelik tutum ölçeği ön-test puanları arasındaki farkın istatistiksel olarak anlamlı olmadığ belirlenmiştir $\left(t_{(61)}=1.283\right.$; $p>.05)$. Buna göre, deneysel işlem öncesinde deney ve kontrol grubunun çevre sorunlarına yönelik tutumlarının benzerlik gösterdiği söylenebilir. Araştırmanın sonunda ise deney ve kontrol grubunun çevre sorunlarına yönelik tutum ölçeği son-test puanları arasında deney grubu lehine istatistiksel olarak anlamlı bir fark olduğu tespit edilmiştir $\left(t_{(61)}=2.379 ; p<.05\right)$. Bu sonuca bakarak, mevcut öğretim programına göre birleştirme tekniğine dayalı çevre eğitiminin, öğrencilerin çevre sorunlarına yönelik olumlu tutumlarının artmasına daha fazla katkı sağladığ 1 söylenebilir. Bu sonuç, Ateş (2004); Ayna, Aktaş ve Koray (2008); Azar (2008); Bilgin ve Geban (2004); Demiral (2007); Hevedanlı ve Akbayın (2006); Kaptan ve Korkmaz (2000); Koçakoğlu ve Solak (2006); Köseoğlu (2010)'nun 
araştırmalarından elde edilen sonuçları desteklemektedir. Ayrıca, deney ve kontrol grubunun kalıcılık testi puanları arasındaki farkın deney grubu lehine istatistiksel olarak anlamlı olduğu belirlenmiş̧ir $\left(t_{(61)}=17.345 ; p<.05\right)$. Buna göre, deney grubunda uygulanan birleştirme tekniği temelli öğretimin öğrenmenin daha kalıcı gerçekleşmesini sağladığı söylenebilir. Elde edilen bu sonuç Azar (2008); Demiral (2007); Hevedanl1, Behçet ve Akbayın (2004)'ın araştırma sonuçlarıyla benzerlik göstermektedir. Öğrenmenin kalıcı izli istendik davranış değişikliği olan genel tanımından yola çıkarak, kalıcı olmayan öğrenmeye öğrenme demek doğru olmayacaktır. Bu tür öğrenme daha çok ezber öğrenmelerde ortaya çıkmaktadır. Ezber öğrenme, kısa süreli bellekten uzun süreli belleğe aktarılan bilgilerin bir süre sonra unutulması olarak da düşünülebilir. Bu anlamda, derslerde kalıcı öğrenmeyi destekleyecek öğretim yöntem ve tekniklerinin kullanılması önemlidir. Bu araştırmada birleştirme tekniğine dayalı öğretimin öğrenmenin daha kalıcı gerçekleşmesini sağladığı sonucuna ulaşılmıştır.

İşbirlikli öğrenme teknikleri öğrencilerin öğrenme sürecine aktif katılımını sağlamakta, bununla birlikte öğrencilerin akranlarıyla etkileşimde bulunmasını sağlayarak, öğrenmede verimliği ve derse karşı ilgiyi artırmaktadır. Üniversitede lisans programlarında bulunan çevre eğitimi dersi konularında, işbirlikli öğrenme tekniklerinin kullanımının yaygınlaştırılması önerilmektedir. Öğrenme ortamlarının işbirliği yönteminin tekniklerine uygun şekilde düzenlenerek, işbirliği uygulamaları için kullanıma uygun duruma getirilmesi, etkili eğitim-öğretim yapılmasına yardımcı olacaktır.

$\mathrm{Bu}$ araştırmanın sonucunda, deney grubunda öğrencilerin başarısının istatistiksel olarak anlamlı ölçüde artması, bununla birlikte çevre sorunlarına yönelik olumlu tutumlarının da pozitif yönde artış göstermesi, birleştirme tekniğine dayalı öğretimin derse olan ilgi ve motivasyonu artırdığı şeklinde yorumlanabilir. Buradan hareketle, birleştirme tekniği temelli öğretimin çevre eğitimi dersi konularında uygulanmasının, öğrencilerin çevre eğitimi dersi akademik başarılarını kalıcı olarak artıracağı ve çevreye karşı olumlu tutum geliştirmelerini sağlayacağı söylenebilir. Bu bakımdan, çevre eğitimi dersinde yer alan farklı konuların öğretiminde birleştirme tekniğinin kullanılabilir. Bundan sonraki yapılacak araştırmalarda, birleştirme tekniğinin lisans düzeyinde farklı programlarda bulunan derslerde ve farklı konulardaki etkililiği incelenebilir.

\section{KAYNAKLAR}

Açııgöz, K. Ü. (2006). Aktif öğrenme. (8. Baskı). İzmir: Kanyılmaz Matbaası.

Altıparmak, M. ve Nakipoğlu, M. (2005). Lise biyoloji laboratuvarlarında işbirlikli öğrenme yönteminin tutum ve başarıya etkisi. Türk Eğitim Bilimleri Dergisi, 3(1), 105-123.

Aranson, E., Blaney, N., Stephan, C., Sikes, J., \& Snapp, M. (1978). The jigsaw classroom. Beverly Hills, CA: Sage.

Arslan, O., Doğan-Bora, N. ve Keskin-Samancı, N. (2006). İşbirliğine dayalı öğrenme tekniklerinin onuncu sınıf öğrencilerinin sinir sistemi konusunu öğrenmelerine etkisi. Eğitim Araşttrmaları, 23(1), 1-9.

Artut-Dinç, P. ve Tarım, K. (2007). The effectiveness of jigsaw II on prospective elementary school teachers. AsiaPacific Journal of Teacher Education, 35(2), 129-141.

Ateş, M. (2004). İşbirlikli ögrretim yönteminin ilköğretim 2. kademesinde madde ve özellikleri ünitesinde ögrrenci başarısına etkisi. (Yayımlanmamış yüksek lisans tezi). Dokuz Eylül Üniversitesi Eğitim Bilimleri Enstitüsü, İzmir.

Ayna, C., Aktaş, M. ve Koray, Ö. (2008). Fen bilgisi dersinde kullanılan işbirlikli öğrenme jigsaw II tekniğinin ilköğretim 7. slnı öğrencilerinin akademik başarı ve derse yönelik tutum düzeyleri üzerindeki etkisi. VII. Ulusal Fen Bilimleri ve Matematik Eğitimi Kongresi, Abant İzzet Baysal Üniversitesi, Bolu.

Azar, N. (2008). Fen ve teknoloji dersinde öğrenme stillerinin işbirlikçi grup atamalarında kullanılmasının ögrencinin akademik başarl, tutum, bilimsel süreç becerileri ve kalıcllı düzeylerine etkisi. (Yayımlanmamış yüksek lisans tezi), Karaelmas Üniversitesi Sosyal Bilimler Enstitüsü, Zonguldak.

Baş, G. (2011). Çoklu zekâ kuramında bir adım daha: Ekolojik zekâ. Bilim ve Aklın Aydınlığında Eğitim Dergisi,134, 7-10.

Bilgin, İ. ve Geban, Ö. (2004). İşbirlikli öğrenme yöntemi ve cinsiyetin sınıf öğretmenliği öğretmen adaylarının fen bilgisi dersine karşı tutumlarına, fen bilgisi öğretimi I dersindeki başarılarına etkisinin incelenmesi. Hacettepe Üniversitesi Eğitim Fakültesi Dergisi, 26, 9-18.

Büyüköztürk, Ş., Çakmak-Kılıç, E., Akgün, Ö. E., Karadeniz, Ş. ve Demirel, F. (2009). Bilimsel araştırma yöntemleri. (9. Baskı). Ankara: Pegem Yayınları.

Choe, S.W.T., \& Drennan, P. M. (2001). Analyzing scientific literature using a jigsaw group activity piecing together student discussions on environmental resarch. Journal of College Science Teaching, 30(5), 328330. 
Cooper, J., \& Mueck, R. (1990). Student involvement in learning: Cooperative learning and college instruction. Journal on Excellence in College Teaching, 1, 68-76.

Demiral, S. (2007). İlköğretim fen bilgisi dersi maddenin iç yapısına yolculuk ünitesinde, işbirlikli öğrenme yönteminin öğrenci başarısına bilgilerin kalıcılı̆̆ına ve derse karşı tutumlarına etkisi. (Yayımlanmamış yüksek lisans tezi). Gazi Üniversitesi Eğitim Bilimleri Enstitüsü, Ankara.

Deniş, H. ve Genç, H. (2007). Çevre bilimi dersi alan ve almayan sınıf öğretmenliği öğrencilerinin çevreye ilişkin tutumları ve çevre bilimi dersindeki başarılarının karşılaştırılması. Mehmet Akif Ersoy Üniversitesi Ĕ̈itim Fakültesi Dergisi, 8 (13), 20-26.

Doymuş, K. (2007). Teaching chemical equilibrium with the jigsaw technique. Research in Science Education, $37(5)$.

Doymuş, K. ve Şimşek, Ü. (2007). Kimyasal bağların öğretilmesinde jigsaw tekniğinin etkisi ve bu teknik hakkında öğrenci görüşleri. Milli Ĕ̆itim Dergisi, 1(173), 231-243.

Eilks, I. (2005). Experiences and reflections about teaching atomic structure in a jigsaw clasroom in lower secondary school chemistry lessons. Journal of Chemical Education, 82(2), 313-319.

Erdoğan, A. ve Özsevgeç, L. C. (2012). Kavram karikatürlerinin öğrencilerin kavram yanılgılarının giderilmesi üzerindeki etkisi: Sera etkisi ve küresel 1sınma örneği. Turkish Journal of Education, 1(2), 1-13.

Erol, G. H. ve Gezer, K. (2006). Prospective of elementary school teachers' attitudes toward environment and environmental problems. International Journal of Environmental and Science Education, 1(1), 65 - 77.

Ghaith, G., \& Mirna, A. E-M. (2004). Effect of jigsaw II on literal and higher order EFL reading comprehension. Educational Research and Evaluation, 10(2), 105-115.

Güven, E. (2013). Çevre sorunları başarı testinin geliştirilmesi ve öğretmen adaylarının bilgi düzeylerinin belirlenmesi. Trakya Üniversitesi Eğitim Fakültesi Dergisi, 3(2), 114-127.

Hançer, A.H., Şensoy, Ö. ve Yıldırım, H.İ. (2003). İlköğretimde çağdaş fen Bilgisi öğretiminin önemi ve nasıl olması gerektiği üzerine bir değerlendirme. Pamukkale Üniversitesi Ĕ̆itim Fakültesi Dergisi, 13, 80-88.

Hevedanlı, M. ve Akbayın, H. (2006). Biyoloji öğretiminde işbirlikli öğrenme yönteminin başarı, hatırda tutma ve derse yönelik tutum üzerindeki etkileri. Dicle Üniversitesi Ziya Gökalp Eğitim Fakültesi Dergisi, 6, 2131.

Hevedanl, M., Behçet, O. ve Akbayın, H. (2004). Biyoloji öğretiminde işbirlikli ögrenme ile geleneksel ögretim yöntemlerinin ögrrencilerin erişileri ve öğrendiklerini hatırda tutma düzeyleri üzerindeki etkileri. XIII. Ulusal Eğitim Bilimleri Kurultayı, Malatya.

Johnson, D.W., Johnson, R.T., \& Smith, K. A. (1998). Maximizing interaction through cooperative learning. ASEE Prism, 7.

Kaptan, F. ve Korkmaz, H. (2000). Iş̧birliğine dayalı fen öğretiminin öğretmen adaylarının özyeterlik düzeylerine etkisi. IV. Fen Bilimleri Eğitimi Kongresi, Ankara.

Karaçöp, A., Doymuş, K., Doğan, A. ve Koç, Y. (2009). Öğrencilerin akademik başarılarına bilgisayar animasyonları ve jigsaw tekniğinin etkisi. Gazi Üniversitesi Gazi Eğitim Fakültesi Dergisi, 29(1), 211235.

Keleş, Ö. (2007). Sürdürülebilir yaşama yönelik çevre eğitimi aracı olarak ekolojik ayak izinin uygulanması ve değerlendirilmesi. (Yayımlanmamış doktora tezi). Gazi Üniversitesi, Ankara.

Keleş, Ö., Uzun, N., ve Varnacı-Uzun, F. (2010). Öğretmen adaylarının çevre bilinci, çevresel tutum, düşünce ve davranışlarının doğa eğitimi projesine bağlı değişimi ve kalıcılığının değerlendirilmesi. Elektronik Sosyal Bilimler Dergisi, 9(32), 384-401.

Koçakoğlu, M. ve Solak, K. (2006). İşbirliğine dayalı ögrenme yönteminin 4. sinıf ögrrencilerinin fen ve teknoloji dersine karşı tutumlarına etkisi. VII. Ulusal Fen Bilimleri ve Matematik Eğitimi Kongresi, Gazi Üniversitesi, Ankara.

Köseoğlu, P. (2010). Biyoloji eğitiminde birleştirme tekniği temelli öğretimin akademik başarı, özyeterlik ve tutuma etkisi. Hacettepe Üniversitesi Eğitim Fakültesi Dergisi, 39, 244-254.

Köseoğlu, F. ve Kavak, N. (2001). Fen öğretiminde yapılandırmacı yaklaşım. Gazi Üniversitesi Gazi Eğitim Fakültesi Dergisi, 21(1), 139-148.

Madden, N., \& Slavin, R. (1983). Effects of cooperative learning on the social acceptance of mainstreamed academically handicapped students. The Journal of Special Education, 17(2), 171-182.

Öztürk, E. (2013). Uluslararası bir çevre eğitimi projesinin fen ve teknoloji öğretmen adaylarının çevre bilincine etkisi. (Yayımlanmamış doktora tezi), Hacettepe Üniversitesi Sosyal Bilimler Enstitüsü, Ankara.

Slavin, R. E. (1990). Cooperative learning: Theory, research and practice. Boston: Allyn\&Bacon.

Stainer, S., Stromwall, L. K., Brzuzy, S., \& Gerdes, K. (1999). Using cooperative learning strategies in social work education. Journal of Social Work Education, p.35.

Şama, E. (2003). Öğretmen adaylarının çevre sorunlarına yönelik tutumları. Gazi Üniversitesi Gazi Eğitim Fakültesi Dergisi, 23(2), 99-110.

Şimşekli, Y. (2004). Çevre bilincinin geliştirilmesine yönelik çevre eğitimi etkinliklerine ilköğretim okullarının duyarlılı̆̆. Uludă̆ Üniversitesi Ĕ̆itim Fakültesi Dergisi, 17(1), 83-92. 
Tarhan, L. V. ve Acar-Şeşen, B. (2008). An application of jigsaw cooperative learning for understanding “AcıdBase theories". XIII. IOSTE Symposium, The Use of Science and Technology Education for Peace and Sustainable Development. September 21-27.

Taştepe, T. ve Aral, N. (2014). Üniversite öğrencilerinin çevresel bilgi ve tutumlarının incelenmesi. Eğitim ve Öğretim Araştırmaları Dergisi, 3(4), 142-153.

Teksöz, G., Şahin, E. ve Ertepınar, H. (2010). Çevre okuryazarlığı, öğretmen adayları ve sürdürülebilir bir gelecek. Hacettepe Üniversitesi Ĕ̈itim Fakültesi Dergisi, 39, 307-320.

UNESCO (1977). Final report: Intergovernmental conference on environmental education. UNESCO: Paris.

Yoldaş, C. (2009). Çevre bilimi dersinin sınıf öğretmeni adaylarının eleştirel düşünme becerileri, erişileri ve tutumlarına etkisi. (Yayımlanmamış doktora tezi). Dokuz Eylül Üniversitesi, İzmir. 